\title{
THE IMPLEMENTATION OF THE REGULATION OF CASH WAQF MANAGEMENT IN HIGHER EDUCATIONAL INSTITUTION IN INDONESIA AND MALAYSIA (A STUDY OF LEGAL SYSTEM THEORY)
}

\author{
Imam Mustofa $^{1^{*}}$, Dri Santoso ${ }^{2}$, Upia Rosmalinda ${ }^{3}$ \\ ${ }^{1 *, 2,3}$ Institut Agama Islam Negeri (IAIN) Metro, Lampung, Indonesia. \\ Email: ${ }^{*}$ mustofaiain@metrouniv.ac.id, ${ }^{2}$ thebigestdri@gmail.com, ${ }^{3}$ upiarosmalinda@ rocketmail.com \\ Article History: Received on $20^{\text {th }}$ February 2020, Revised on $27^{\text {th }}$ May 2020, Published on $5^{\text {th }}$ July 2020
}

\begin{abstract}
Purpose of the study: This article aims to elaborate on the practice of cash waqf management in a higher educational institution in Indonesia and Malaysia. In further explanation, it will elaborate on the effectiveness of regulation application on cash waqf management by applying Friedman's legal system theory. This paper also explores some obstacle factors towards the implementation of cash waqf regulation in higher education.
\end{abstract}

Methodology: This study applies a qualitative approach by using two main data resources, primary and secondary data. The data collection method applied in this research is by conducting documentation and interviews with stakeholders of cash waqf managers in higher educations in Indonesia and Malaysia. The collected data were analyzed by the legal system theory.

Main Findings: In the level of legal substance, both Indonesia and Malaysia have been sufficiently rigid and representative. The regulation of waqf in Malaysia gives discretion to waqf administrators to improve waqf management. Meanwhile in Indonesia, the implementation of the regulation on waqf management is still plagued by social norms and religious norms that are believed by communities.

Applications of this study: The result of the study aims to contribute to cash waqf management and its development in Indonesia, particularly in higher education. The study is expected to be a platform and foundation in the implementation of cash waqf regulation and its management model. Furthermore, the results of this study are expected to be considered in strengthening the development of legitimacy and regulation in the education sector.

Novelty/Originality of this study: This study focuses on the implementation of waqf regulations in the higher education institution in Malaysia and Indonesia based on the perspective of legal system theory. The implementation of the waqf regulation in both countries is analyzed by three aspects; substance aspects, structural aspects, and legal culture aspects.

Keywords: Cash Waqf, Regulation, Higher Educational Institution, Legal System Theory.

\section{INTRODUCTION}

The role of waqf in Islamic education has been existing since the era of Abasyiyah and the Ottoman Imperium (Azra, 2004, pp. 55-67). Waqf is currently developed for social needs such as health, religion, education, and other purposes, (Sya'bani, 2016, p. 174) such as relief of poverty, public and religious constructions (Ghazaleh, 2011, p. 23). The use of waqf is optimized to support the education sector such as in some universities and non-formal education as in Pondok Pesantren (Islamic boarding school) (Fanani, 2011, p. 183). The waqf assets are also used for educational development starting from primary level to higher education level, for example as Institut Agama Islam Negeri (IAIN), Universitas Islam Negeri (UIN), Universitas Islam Indonesia (UII), Universitas Muslim Indonesia (UMI), Universitas Muhammadiyah Jakarta (UMJ), Universitas Islam Sumatera Utara (UISU) and many more (Tim Direktorat WakafDirjen Bimas Islam Kemenag RI, 2013, p. 86).

Today's waqf development can be said entering into the professional period, on which the empowerment of waqf assets is developed productively without decreasing its original values (Suryani \& Isra, 2016, p. 23). The benefits of the waqf are also used for other needs that are relevant to the purpose of waqf (Qahaf, 2006, pp. 33-34). In general, Muslim countries have specific units in managing waqf property administration (Ab. Rahman, 2009, pp. 121-122). In Indonesia, waqf is managed by the government and other institutions particularly Indonesia Waqf Council or Badan Wakaf Indonesia (BWI) (Anonim, 2005). Meanwhile, in Malaysia, waqf is managed by Jabatan Wakaf, Zakat dan Haji (JAWHAR) (Hamid, 2016). Some higher educational institutions have practiced the implementation of cash waqf management very well, some of them are Yayasan Badan Wakaf Universitas Islam Indonesia Yogyakarta, Yayasan Badan Wakaf Sultan Agung Semarang, Yayasan Badan Wakaf Pondok Modern Gontor Ponorogo dan Yayasan Hasyim Asy'ari Pondok Pesantren Tebuireng Jombang (Bamualim \& Abubakar, 2005, pp. 217-296). The same management as in Malaysia, waqf is used to develop Madrasah (school) Masyhor al-Islamiyah in Pinang Island, Kolej Islam Sultan Alam Shah in Kelang, and others (Faiza, 2015, p. 168). Some higher institutions that become waqf administrators are USIM, IIUM, Universiti Putra Malaysia, and others (Mahamood \& Ab Rahman, 2015; Salleh \& Abdul Rahman, 2014).

Waqf regulation in Indonesia is written in various regulations, including the regulation on cash waqf. Those waqf regulations were written under 1) Law Number 41 the Year 2004 on Waqf; 2) The Government Regulation of the Republic of Indonesia Number 42 the Year 2006 on the Implementation of Law Number 41 the Year 2004 on Waqf; 3) 
The Government Regulation of the Republic of Indonesia Number 25 the Year 2018 on the Changes of the Government Regulation of the Republic of Indonesia Number 42 the Year 2006 on the Implementation of Law Number 41 the Year 2004 on Waqf; 4) The Regulation of Minister of Religious Affairs of the Republic of Indonesia Number 4 the Year 2009 on Registration Administration of Cash Waqf; 5) The Regulation of Minister of Religious Affairs of the Republic of Indonesia Number 73 the Year 2013 on the Procedures of Waqf on Movable and Immovable Object except for Money; 6) The Regulation of Indonesia Waqf Council Number 4 the Year 2010 on the Guidelines of Waqf Wealth Management and Development; 7) The Standpoint of Indonesian Scholars Council (MUI) on Cash Waqf in 2002.

Waqf System in Malaysia is regulated by several Law, namely Konstitusi Federal (Federal Constitution) 1957, Kode Tanah Nasional (National Land Code) 1965, Islamic Law Administration (Federal Territories) Act 1993 (Act 505 ), Pemberlakuan Selangor Wakaf (No. 7 dari 1999), Trustee Act 1949 (Act 208), Malacca Waqf Enactment 2005, Negeri Sembilan Wakaf Enactment 2005 and each Islamic Law Enforcement Administration from several states and also other constitutions that related to waqf administration such as Trustee Act 1949, Specific Relief Act 1950, Contracts Act 1950, Enactment 15 Year 2015, Waqf Enactment (Negeri Selangor) and others (Mohamad, n.d., p. 1).

In Malaysia, waqf administrator is under the authority of the Religious Council in each state that has a department and unit to manage the administration of waqf properties (Dahlan et al., 2014, p. 59). This policy aims to give independence to each state in improving waqf development. Concerning the regulation of cash waqf in Malaysia, because this study is located in Sembilan State and Selangor State, thus the regulation mentioned in this research is the regulations that apply in both States.

This study is a comparative study that is conducted both in Indonesia and Malaysia. This study aims to elaborate on the effectiveness of cash waqf regulation that is applied in higher education both in Indonesia and Malaysia by the approach of Lawrence M. Friedman's legal system theory.

\section{LITERATURE REVIEW}

Cash Waqf is popularized by MA Mannan (Maksum, t.t., pp. 6-7). Cash Waqf is one type of productive waqfs. Cash waqf provides an opportunity for people who want to contribute but have little capital.

Cash Waqf (Waqf al-Nuqud) is a waqf made by a person, group of people, institutions, or legal entities in the form of cash, including the securities. Cash waqf is jawaz (allowed). The principal value of the cash waqf and its sustainability must be guaranteed, may not be sold, granted, and / or bequeathed. (Fatwa MUI tentang wakaf uang tertanggal 28 Shafar 1423 H / 11 Mei 2002, n.d. also read; Khademolhoseini, n.d., p. 3; Nurrachmi, 2013, p.4).Cumulative funds of cash waqf can be used as capital for investment (Rahman, 2009, p. 88).

The studies on the use of cash waqf for the development of higher educational institutions have been done a lot. Mu'alim examines the effect of waqf management on al-Azhar educational institutions on waqf management at the Universitas Islam Indonesia. This study found that normatively there were no rigid provisions regarding the management of waqf for educational institutions. This research implied that the management of waqf in educational institutions can be applied more flexibly, and placing the foreign educational institutions as a role model (Mu'allim, 2015). Unfortunately, the management of waqf in Indonesia is performed rigidly through various rules - law to the fatwa of the Indonesian Ulema Council (MUI).

Hasan found that the implementation of regulation implementation on cash waqf still is constrained by the social paradigm toward waqf, and understanding and interpretation of waqf regulations in Indonesia (Hasan, 2010). In Indonesia, the implementation of cash waqf regulation has different policies between an institution and other institutions. This problem occurred because of different understandings and interpretations of the existing rules. Besides, the practice of cash waqf management is also different from the concept of the constitution (Hilmi, 2012) as well as the implementation of waqf in higher education. For instance, cash waqf at Universitas Muslim Indonesia (UMI) the application has referred to Law Number 41 the Year 2004, however, the existing rules in the constitution have not been fully implemented (Mughnisani \& Lutfi, 2013). This research will not investigate the problems of rules implementation on cash waqf management at UMI.

Othman et al did a scientific review on the development of higher education that used the fund of cash waqf. This study was done at Universiti Insaniah. The waqf implementation by any organization must obey the regulation of Religious Affairs. This covered the implementation of waqf in higher education in Malaysia that used waqf as alternative financing sources. The implementation of cash waqf that was used to fund Kolej Universiti INSANIAH (KUIN) will follow the same law process as waqf center council of higher educational institutions (Othman et al., 2017).

Masdar researched the implementation of cash waqf law in Indonesia by using legal system analysis. However, Masdar in his study did not only mention the constitution and other regulations but also mentioned the Standpoint of Majelis Ulama Indonesia and BWI's regulation as a legal substance of cash waqf. This research summed up that in the implementation of cash waqf regulation, both in the aspect of legal substance and legal structure had no problem. However, it also mentioned that the legal culture aspect became a barrier. Society's perception has not indicated positive thought towards cash waqf and institution of cash waqf administrators such as Badan Wakaf Indonesia. Some of them 
allowed the utilization of cash waqf but some of them didn't. Moreover, the term cash waqf has not been familiar with society (Masdar, n.d.).

Law enforcement in cash waqf administrators is constrained by the legal culture that goes into an important component of law enforcement. The legal culture components in legal system theories are (1) structure, (2) substance, and (3) legal culture (Yunus, 2015, p. 40). Those three components in law enforcement are often used as a standard reference to measure law enforcement in a country.

The legal system in Friedman's theory at least contains three elements, they are the legal structure, legal substance, and legal culture. These structures become a fundamental element of the legal system. The substances (regulations) are other elements. The structure of the judicial system is interpreted as judges, court jurisdiction, on how the higher court is above the lower court and other kinds of court. Meanwhile, the substances are arranged from regulations and provisions on how institutions should act (Friedman, 2013, pp. 15-16).

The structures and substances are real components of the legal system, but all of them are just a blueprint or prototype, not a working machine. The legal system that is described as formal structure and substance is like a silent courtroom because of bewitched, frozen, and stopped under a magic spell towards an odd occasion. The thing that gives spirit, color, and reality in legal is external social, a culture of a community. Legal culture is the attitude element and social value. The term "social powers" is an abstract; however, those powers indirectly drive the legal system. People in a community have needs and demands; these all sometimes don't cover and reach the legal process - depends on the culture (Friedman, 2013, pp. 16-17).

"Law operates not only on the level of doctrine or legal officials, but also infuses culture and is fused to it, creating a culture of law" (Admiral, 2018, p. 233). A community lives in social behavior because culture covers a pack of values and attitudes that relate to law, which decide questions of what, why, and when community approaches legal system or government or avoid both of them (Yunus, 2015, p. 41). It needs to be emphasized that the law needs political authority as a condition for its enforcement; it also needs moral authority as a condition for its social recognition (Guibentif, 2007. p. 633).

A system is not isolated or alienated, it relies on external inputs. Without cases, there will be no court. Without problems and efforts to solve it, there will be no inmates. This social element melts down the rigidity of problems above, and drive the system (Friedman, 2013, p. 17).

\section{METHODOLOGY}

The method used in this research is a qualitative method by putting forward a deep understanding of the concept of cash waqf, cash waqf regulation in Malaysia and Indonesia, and its contribution to developing higher education. The main step of the study is to unify researchers' perceptions because this research involves three researchers. This aims to have the same direction which can result in research outcome as expected.

The data in this research generally consists of two data, primary data such as interview, and secondary data such as written data of the relevant document. The sources of primary data are informants of waqf fund administrators that use waqf to fund education in both Indonesia and Malaysia. Meanwhile, the sources of secondary data are documents and written references of journals, research results, books, magazines, electronic data sources, and other relevant sources that relate to cash waqf management used to develop the higher educational institution.

The data collection technique used in this research is by interviewing research participants in person that are located in Malaysia and Indonesia to dig knowledge and information in-depth as well as data needed. After collecting data, the researchers classify data based on each country by the aim to ease data analysis and result in good data analysis.

The method used in this research relates to two things; data collection method and data analysis method. The data collected in this research used two data collection methods.

First, it used a semi-structured interview. A semi-structured interview is a method of an interview that is done by the interviewer by asking a series of questions that have been structured and prepared, which then asked in-depth to gain further information (Arikunto, 1993, p. 197) and in-depth interview is a method used to gain accurate information the relates to the problem researched (Koentjaraningrat, 1991, pp. 138-140).

Second, it used documentation. Documentation is used to gain secondary data by collecting documents and literature that relate to this research, particularly on cash waqf management that used its fund to develop higher education.

Regarding data analysis, qualitative data in this research is analyzed by a descriptive-analysis method that is a method in researching a group of people, an object, a situation and condition, and a thought system. Descriptive research aims to describe a figure systematically, factually, and accurately regarding the facts and its relation to phenomena that are researched (Nazir, 1988, p. 10; Soekanto, 1986, p. 10).

Data analysis data is done by several steps as follows: The first is collecting data that is an activity to find and compile sources of information that are relevant to the research. The second is Interpreting data that is a step in arranging facts of 
the logical and harmonious framework, thus becoming complete data. The third is writing, that is a step when the interpretation result is written systematically, logically, harmoniously, consistently, either in terms of words or plot of discussion. Theoretically, data analysis is a process to arrange, categorize, and search the pattern or theme of data by understanding its meaning (Moleong, 1989, pp. 4-8).

In this qualitative research, three main components will be gone through by researchers, they are data reduction, data display, and conclusion drawing (Sutopo, 1988, p. 34). These three analysis components apply to ensure each other either before, during, and after collecting data in parallel. This analysis generally is mentioned as a flow model of analysis.

The data gained directly from the research object has been equipped with a theoretical study that is specialized only for the theory of cash waqf. In short, the method above will be explained through the following chart:

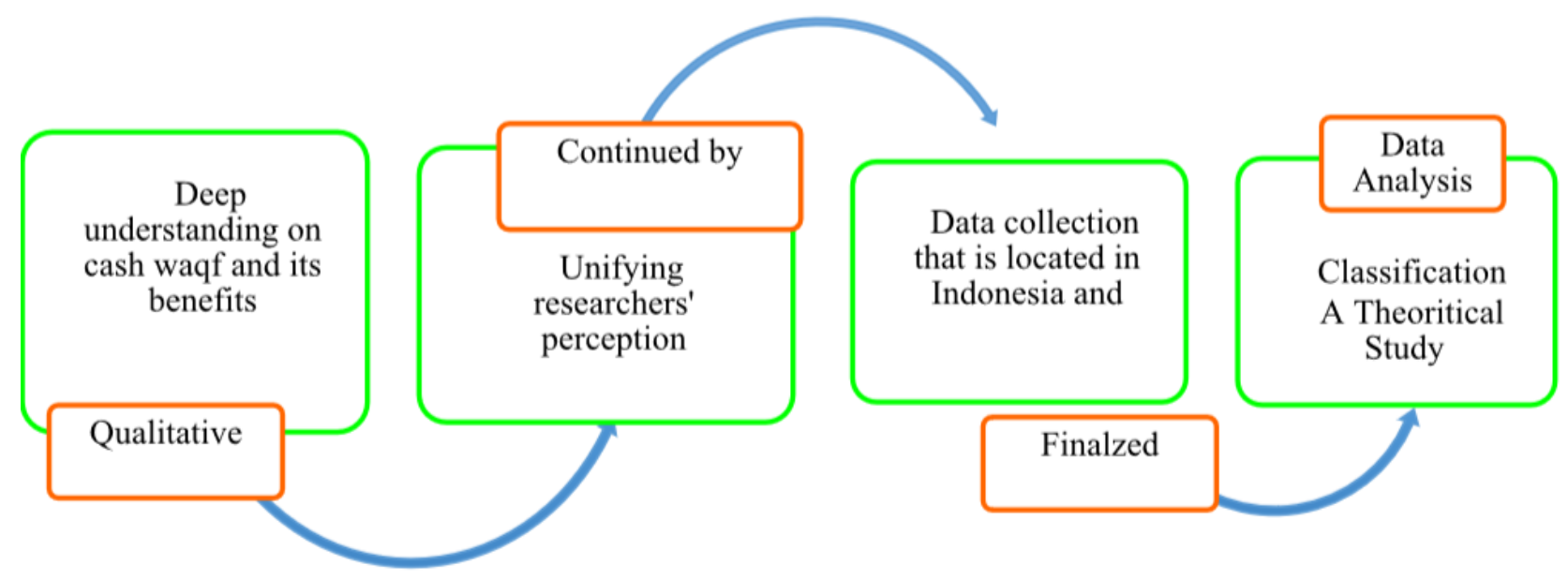

Figure 1: Data Analysis Method

\section{RESULTS/FINDINGS}

\section{The practice of cash waqf management in higher education in Indonesia.}

Universitas Muslim Indonesia Waqf Foundation is a body that manages various activities such as education, research, social services, business, and health which are based on Islamic principles (Mughnisani \& Lutfi, 2013, p. 3). The transaction of cash waqf is by mentioning that the payment is a transaction for cash waqf during akad, but is not mentioned and stated in the certificate. The fund of cash waqf is saved in Syariah financial institution, which is Bank Muamalat Indonesia (BMI) branch office South Sulawesi (Rusdjin, personal communication, 4 June 2019). It has not been included cash waqf from other sources. The sources of cash waqf come from waqf, infaq, shadaqoh, students' tuition fees, donations, and other sources (Mughnisani \& Lutfi, 2013, p. 15).

The cash waqf implementation is different from cash waqf concepts mentioned in the constitution and other regulations on cash waqf in Indonesia. The operational activities did not fully go because the human resources as administrators in organizational structure are generally lecturers and administration staff at Universitas Muslim Indonesia, so in doing their responsibility.

The cash waqf implementation at Universitas Islam Indonesia (UII) recognized as failed implementation since 15 or 20 years ago. UII only has one experience in handling cash waqf (M. Suwarsono, personal communication, 27 June 2019 ). The wealth that is managed by YBW UII relatively come from student tuition fees (SPP), Waqf, Grant (Hibah), Shodaqoh, Infaq, Zakat, and Legal business units. (Mu'allim, 2015, p. 115). During the process of asset collection, not all assets are gained through akad (covenant) of waqf, and cash waqf is not always done through administration, certification, and registration as mentioned in waqf regulations in Indonesia.

Meanwhile, the practice of cash waqf at Pesantren and the University of Darussalam Gontor look the same as what happened at UII. Pondok Modern Darussalam Gontor in Ponorogo was the first pesantren recorded as taking the initiative to have a formal waqf foundation, which focused on developing the healthcare sector (Mohsin et al., 2016, p. 110). There is indeed some party who did waqf in the form of cash, however, there is no registration administration of cash waqf as regulated in constitutions and government regulations. Current waqf development is influenced by immovable objects. Business units like canteen, laundry services, homestay, and other services. 


\section{The Practice of Cash Waqf Management in Higher Education in Malaysia}

Center of Waqf and Zakat (PWZ), Universitas Sains Islam Malaysia (USIM) has done an initiative approach to support waqf as the main agenda of the university. This is done through the USIM Cash Waqf Program Development, Tapak Waqf Program, Educational Waqf Program.

Center of Waqf and Zakat USIM manages three waqf categories: cash waqf, tapak waqf, and educational waqf. Cash waqf (Wakaf Al-Abrar Fund) is the effort of USIM to be a pioneer and stimulus of endowment development. This is done by USIM through two considerations; First, the awareness to optimize waqf as high potency to contribute to the development of the community social economy, Second, the prediction of the future, public universities will be asked by the government to involve in waqf financing or to raise funds for government funding.

There are six ways to do waqf through Waqf and Zakat Center (PWZ) USIM. 1) Waqif may transfer to the USIM bank account directly through Bank Islam Malaysia Berhad (BIMB). Waqif may transfer and bring the transfer proof to Zakat and Waqf Center USIM to be validated if necessary. However, those do waqf (secretly) through the blind way, they don't need to validate to waqf center and only write their names in the name of Hamba Allah. 2) Waqif may do waqf through the salary deduction system. The scheme of salary deduction can be done by staff and faculty members of USIM or other institutions outside USIM. 3) Waqif may donate through a bank check. Those who will do waqf by this method, they can do it in the name of USIM. 4) Those who want to donate the waqf fund, they can do it through JOMPAY. 5) Waqif can also do waqf through the counter at USIM Zakat and Waqf Center USIM. 6) Waqif may do waqf through the portal of Waqf and Zakat Center USIM by choosing a menu of Express Waqf. There is no obligation of cash waqf certification.

The project and waqf assets in Waqf and Zakat Center USIM are used for; 1) medical clinic, health specialist clinic USIM including Hemodialysis clinic; 2) second, campus housing to accommodate students both inside and outside USIM campus; 3) the development of USIM Convention Center and USIM Hotel Tower which located at the intersection between USIM and MESAHIL.

Another higher institution that manages cash waqf is Koleh Universiti Islam Antarbangsa Selangor (KUIS) located in the region of Selangor State. KUIS may receive waqf distributed via bank. The collaboration between MAIS and some commercial banks also offer cash waqf transaction through ATMs. Generally, waqf at KUIS is only in the form of Educational Waqf.

Following waqf management, KUIS performs as deputy of agent that is responsible to do waqf fundraising. The representatives of KUIS are inaugurated by Majelis Agama Islam Selangor. The waqf management at KUIS is under the Department of Zakat, Waqf, and Infaq that also coordinate with Wakaf Selangor (PWS). As the agent, KUIS only does all regulations and policies that are specified by PWS regarding waqf fund collections and its distribution.

Waqf stock participation at KUIS can be conducted in three ways; 1) bank transfer, 2) salary cut scheme, 3) direct deposit to the office of Department of Zakat, Waqf, and Infaq KUIS. The certificate publication of waqf is made only for those who pay waqf at least RM. 10.00. However, due to a limited budget, this certification was stopped in 2017 (R. N. Ashikin, personal communication, 10 September 2019).

The waqf fund that has been collected can be used to buy assets under the agreement of Majelis Agama. The assets that are bought from waqf funds are in the form of a mosque, student dormitory, office, library, academic office, and learning center (R. N. Ashikin, personal communication, 10 September 2019). Waqf fund also used to help students to fund their study through Darmasiswa tahts prioritized for students of the low economy.

\section{DISCUSSION / ANALYSIS}

Looking at what happened at Universitas Muslim Indonesia, Makassar, in which waqif must do registration, have witnesses, be certified as regulated by constitution, and government regulation, as well as regulation of Minister of Religious Affairs, thus many people prefer to choose infaq or shadah. This is because waqf regulation is too rigid.

Waqf practice that happened in society cannot guarantee the legality of waqf object or optimization of the waqf object function. Based on this fact, thus waqf regulation furthermore is made to give legality and its optimization to create waqf fundraising that can be beneficial to find its potency in society. The function of law is to protect and give a guarantee and legal certainty (Agrast \& Rožman, 2018; Rosadi \& Effendi, 2018).

The role of cash waqf management to develop higher institutions in Indonesia has not run as mentioned in the constitution that aims to develop a social economy based on Syariah law. There are some factors found that related to the effectiveness of cash waqf. There are some problems that found an obstacle in cash waqf management and development in higher education in Indonesia;

First, the certification obligation of waqf object is a must, particularly cash waqf, meanwhile, its urgency still has not been understood, thus people refuse to do waqf, as in their opinion that infaq is also similar to waqf as part of worship. This phenomenon indicated the conflict between legal substance and legal culture, which norms in formal law do not relate to the values that the community believes. 
Second, the habit of society to pay zakat, infaq, and shodaq in Ramadan month causes the ineffectiveness of cash waqf fundraising, because at the same time they will have spent their money on zakat, infaq, and shadaqoh. Thus this will be difficult to do cash waqf fundraising as it contrasts with social behavior.

Third, Lembaga Keuangan Syariah Penerima Waqaf Tunai (LKSPWU) has not prepared yet cash waqf management. LKSPWU has not fully accepted the deposit of cash waqf. This unpreparedness relates to the facilities provided, and the use of cash waqf through investment.

Fourth, the support from the regional government or other stakeholders toward the implementation of cash waqf is still not enough, meanwhile, the support of the government in cash waqf fundraising can increase community awareness to do waqf.

The role of government, public figures, religious leaders in developing cash waqf has not been real. Whereas, the effectiveness of regulation that must be obeyed by the community depends on them as a legal structure.

Concerning the effectiveness of the legal system (cash waqf regulation) in Indonesia, Friedman's theory that is wellknown as legal system theory (legal structure, legal substance \& legal culture) can be a standard in analyzing the ineffectiveness factors of cash waqf in Indonesia. Ministry of Religious Affairs, Regional Government, LKSPWU, and Waqf Administrators are the legal structure which decides the optimization and the effectiveness of cash waqf management in the educational sector in Indonesia (Islamiyati et al., 2019).

Nevertheless, law enforcement is not only decided by its legal structure but also relates to legal culture in a community (Nuzul, 2017; Hoecke \& Warrington, 1998). The legal culture that is meant here is the external legal culture that relates to values, perceptions, behavior, and habit of society towards cash waqf and its management.

The three elements mentioned by Friedman has not been implemented very well, especially in legal culture and legal structure. For example, the community is reluctant to pay cash waqf because the only thing they know is object waqf not cash waqf. The community does not get used to doing waqf with the publication, certification. Besides, they also don't want to pay waqf, zakat, or infaq through official procedures, moreover, they should be registered to LKSPWU.

In comparison to Malaysia, there are different terms, regulations, and legal systems (Islamic law) between Malaysia and Indonesia that bring a significant influence on the development of cash waqf. Malaysia uses the term 'wakaf tunai' to mention cash waqf or waqf in the form of money. The use of the term of cash waqf in waqf regulation implies psychologically to the community who want to do waqf. No matter what the purpose is, whether, for productive assets, investment, or in any form, the community can do waqf in cash. It is different from Indonesia in which the term of cash waqf applies if only used for investment or purchase of productive assets. If it is not productive, even though it is given in the form of cash, this will note mentioned as cash waqf but mentioned as waqf in the form of money.

Although each state in Malaysia has different regulations on waqf (Enactment), in general, the regulation gives freedom to those who want to do cash infaq.

The analysis of the legal structure on cash waqf looks different between Indonesia and Malaysia. In Malaysia, every state has Majelis Agama (Religious Council), this council sometime can be asked for giving the point of view about waqf, including cash waqf. The point of view made the Religious Council is binding as Enactment (Ansori, 2017; Mehmood et al., 2015).

The legal substance application both in Indonesia and Malaysia has been quite rigid and representative. However, waqf regulation in Indonesia applies in all regions in Indonesia, meanwhile, in Malaysia, the regulation is made by Majelis Agama in each state. Indonesia has the same Religious Council namely Majelis Ulama Indonesia (MUI) in each region, however, the point of view of MUI is not binding as the constitution or government regulation.

Waqf regulation in Indonesia is sufficiently rigid. Moreover, to regulate waqf, Minister of Religious Affairs made specific regulations regarding cash waqf administration as mentioned in the regulation of the Religious Affairs Minister. Meanwhile, in Malaysia, cash waqf is only regulated as part of State Enactment.

The existence of rigid waqf regulation in Indonesia aims to protect waqf assets and guarantees asset security. Moreover, cash waqf in Indonesia must be used for a productive thing, including investment, thus legal certainty should be protected by the constitution. In contract, this made cash waqf development obstructed, including cash waqf management in higher education.

In Malaysia, waqf regulation gives freedom to people to choose kinds of waqf, such as khas (specific) waqf, 'aam (general) waqf, cash waqf, tapak waqf, moreover, cash waqf is divided into several sectors; education, health, investment. Malaysia also offers several methods to pay waqf such as bank transfer, salary cut, and mobile application that is currently developed (Norzilan, 2018).

In the matter of legal culture, there is no significant difference between Indonesia and Malaysia, particularly waqf problem. This is because both countries are adequately similar. In terms of religion, worship, and mu'amalah, both 
countries are also the same as the Muslim majority in Malaysia follow madzhab of Syafi'i as in Indonesia. However, regarding waqf culture, Malaysia has a positive perception and supports its practice.

Legal substance about waqf in Malaysia implies legal culture in the community, including higher education. Even though the regulation is so rigid, but Malaysia gives discretion to waqf administrators to improve its management. This is also supported by adequate facilities to implement cash waqf, particularly for the development of education in higher institutions (

In higher education in Malaysia, either mutawalli or nazhir is ready to give adequate infrastructures to people who will do waqf. Various facilities for waqf fundraising or investment are provided by waqf administrators (Harun \& Possumah, 2016).

Malaysian Government seriously supports waqf development program in every organization willing to be nazhir, mutawalli, or agent. Not only does the aid provide waqf regulation, but also provides waqf development infrastructure, fund, as well as human resources. The government did this for the development of progressive waqf, especially cash waqf. Besides the Central Waqf Council (Malaysia Waqf Foundation), each state in Malaysia also has a waqf council that manages waqf development and management (Azha et al., 2013).

The cooperation between the waqf administrator and banks in Malaysia runs very effectively. To develop the waqf collection, Waqf Council A also does cooperation with Bank A as a strategic partner. Cash waqf also has successfully been launched by Bank to collect waqf from the community. Komite Manajemen Bersama (JMC) is formed by the Bank and Religious Council to manage cash waqf. This all runs very well. All waqf institutions can easily approach the bank. Jurisdiction limitation does not preclude for the transaction between Waqf Institution and Bank (Mohammad, 2011, p. 384).

Malaysian Government fully supports cash waqf management in higher education. This support made a synergistic relationship among three main elements of waqf regulation managers, based on Friedmann's theory mentioned above, a legal substance, legal structure, and legal culture. The support of government and the synergistic relationship of three elements on the implementation of cash waqf regulation in higher education can be seen in the following figure:

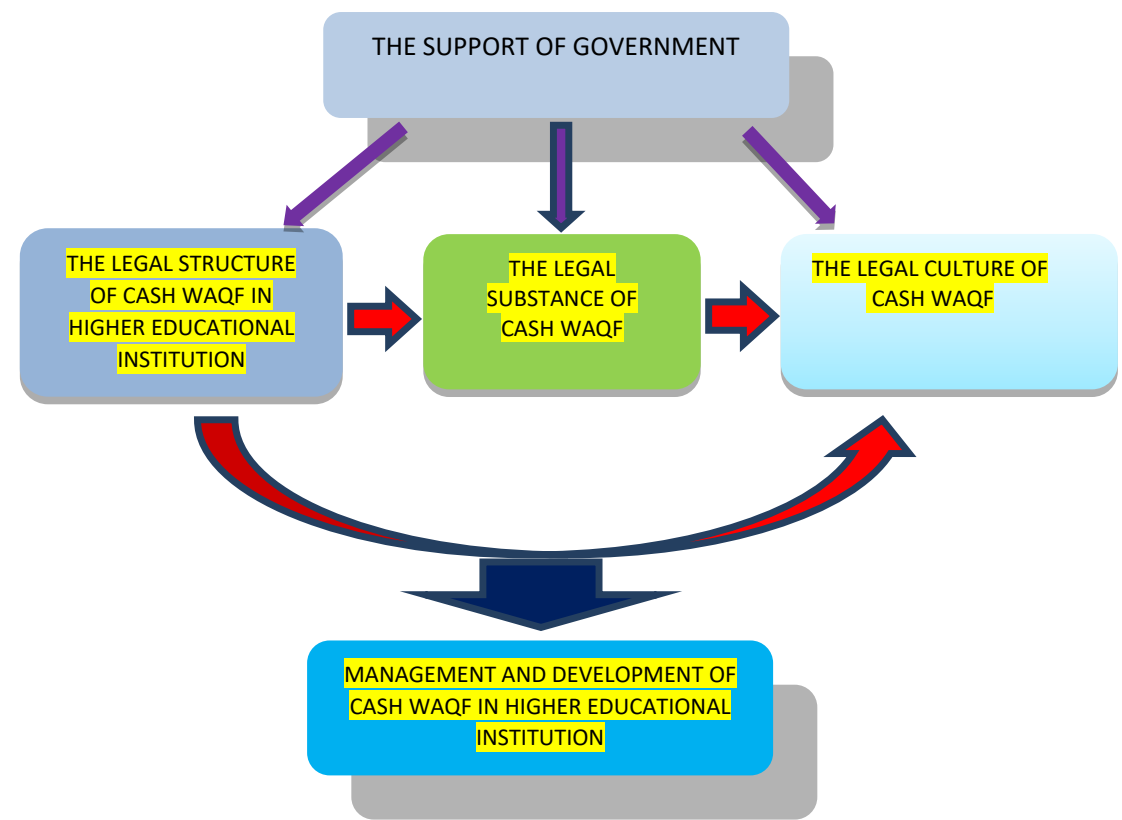

Figure 2: The support of government and the synergistic relationship of three elements; legal substance, legal structure and legal culture

\section{CONCLUSION}

Waqf regulation in Indonesia has not been effective, moreover can be said as a barrier for waqf development. The regulation has not been understood by the community, including policymakers, and waqf administrators. Waqf regulation in the form of registration, certification, distribution of cash waqf has not been maximized in higher education.

Meanwhile, in Malaysia, cash waqf management and system in higher education is more advanced compared to Indonesia. Cash waqf regulation is made by the Religious Council in each state which further is decided as binding law or Enactment. This regulation made waqf administration easier in developing waqf management in higher education.

Indonesia and Malaysia have some differences in terms of 'cash waqf', either in its regulation and implementation. Cash waqf regulation in Indonesia must be in the form of money, but it also has the limitation that it must be used 
productively. Cash waqf also must be protected, not be a sale, not be granted, and not be bequeathed. Meanwhile in Malaysia, all waqf in the form of cash can be said as cash waqf, whether it is used for a productive thing or not. These different terms imply the implementation of waqf in both countries.

In the level of legal structure, Malaysia gives authorities to the community to manage cash waqf, Religious Council has full authority to make cash waqf regulation in legal substance, both in Indonesia and Malaysia is adequately rigid and representative. However, waqf regulation in Indonesia applies in all regions in Indonesia. Meanwhile in Malaysia, the regulation is made by Majelis Agama in each state. Indonesia has the same Religious Council namely Majelis Ulama Indonesia (MUI) in each region, however, the point of view of MUI is not binding as the constitution or government regulation. Legal substance about waqf in Malaysia implies legal culture in the community, including higher education. Even though the regulation is so rigid, Malaysia gives discretion to waqf administrators to improve its management in higher institutions. Meanwhile in Indonesia, cash waqf regulation is limited by sociological norms and religious norms believed by the community. The community also doesn't obey the regulation because they believe that this all is mentioned in the classical fiqh.

\section{LIMITATION AND STUDY FORWARD}

This study is limited to the implementation of cash waqf regulation management in higher education. It is needed to conduct further research to review cash waqf implementation in the wider institution.

\section{ACKNOWLEDGMENT}

The current research was funded under the center of Research and Community Services- Islamic State Institute Metro, Lampung Indonesia.

\section{AUTHORS CONTRIBUTION}

All the authors of this article contribute to this study. The first author formulized the research method of this study and analyzed the collected data. The second Author reviewed the literature that relates to the research. Meanwhile, the third author did data collection and wrote as in writing guidelines.

\section{REFERENCES}

1. Ab. Rahman, A. (2009). Peranan Wakaf Dalam Pembangunan Ekonomi Umat Islam Dan Aplikasinya Di Malaysia. Shariah Journal, 17(1).

2. Admiral, R. (2018). Living Islamic Law: Women and Legal Culture in Marinid Morocco. Islamic Law and Society, 25(3), 212-234. https://doi.org/10.1163/15685195-00253P02

3. Agrast, M. D., \& Rožman, P. (2018). World justice project Rule of law index: 2017-2018. The World justice project.

4. Anonim. (2005). , Paradigma Baru Wakaf di Indonesia. Direktorat Pengembangan Zakat dan Wakaf Direktorat Jenderal Bimbingan Masyarakat Islam dan Penyelenggara Haji.

5. Ansori, I. (2017). Kedudukan Fatwa di Beberapa Negara Muslim (Malaysia, Brunei Darussalam dan Mesir). Analisis: Jurnal Studi Keislaman, 17(1), 137. https://doi.org/10.24042/ajsk.v17i1.1790

6. Arikunto, S. (1993). Prosedur Penelitian Suatu Pendekatan Praktik. Rineka Cipta.

7. Ashikin (Senior Assistant Registar, Deputy Rector Corporate Management Kolej Universiti Antarbangsa Selangor, R. N. (2019, September 10). Wakaf Uang di Malaysia: Praktik di Kolej Universiti Islam Antarbangsa Selangor [Personal communication].

8. Azha, L., Baharuddin, S., Sayurno, Salahuddin, S. S., Afandi, M. R., \& H., H. A. (2013). The Practice and Management of Waqf Education in Malaysia. Procedia - Social and Behavioral Sciences, 90, 22-30. https://doi.org/10.1016/j.sbspro.2013.07.061

9. Azra, A. (2004). Jaringan Ulama Timur Tengah dan Kepulauan Nusantara Abad XVII dan XVIII Akar Pembaharuan Islam Indonesia (edisi revisi). Kencana.

10. Bamualim, C. S., \& Abubakar, I. (2005). Revitalisasi Filantropi Islam. PBBUIN Syarif Hidayatullah.

11. Dahlan, N. K., Yaa'Kub, N. I., Hamid, M. A., \& Palil, M. R. (2014). Waqf (Endowment) Practice in Malaysian Society. International Journal of Islamic Thought, 5(1), 6. https://doi.org/10.24035/ijit.05.2014.007

12. Faiza, N. (2015). Rekonstruksi Pengelolaan Wakaf: Belajar Pengelolaan Wakaf dari Bangladesh dan Malaysia. UNIVERSUM, 9(2), 161-171. https://doi.org/10.30762/universum.v9i2.83

13. Fanani, M. (2011). Pengelolaan Wakaf Tunai. Walisongo: Jurnal Penelitian Sosial Keagamaan, $19(1), 179$. https://doi.org/10.21580/ws.19.1.217

14. Fatwa MUI tentang wakaf uang tertanggal 28 Shafar 1423 H / 11 Mei 2002. (n.d.).

15. Friedman, L. M. (2013). Sistem Hukum: Perspektif Ilmu Sosial. Nusamedia.

16. Ghazaleh, P. (Ed.). (2011). Held in trust: Waqf in the Islamic world. American University in Cairo Press.

17. Guibentif, P. (2007). Law, Culture and society. Legal Ideas in the Mirror of Social Theory by Roger Cotterrell. Journal of Law and Society, 34(4), 633-638. https://doi.org/10.1111/j.1467-6478.2007.00408.x

18. Hamid, S. S. A. (2016). 11.091,82 hektar Tanah Wakaf. Harian Metro.

19. Harun, F. M., \& Possumah, B. T. (2016). Issues and Economic Role Of Waqf In Higher Education Institution: Malaysian Experience. 8, 21. https://doi.org/10.15408/aiq.v8i1.1997 
20. Hasan, S. (2010). Wakaf Uang dan Implementasinya di Indonesia. Journal de Jure, 2(2). https://doi.org/10.18860/j-fsh.v2i2.2976

21. Hilmi, H. (2012). Dinamika pengelolaan wakaf uang: Studi sosio-legal perilaku pengelolaan wakaf uang pasca pemberlakuan UU No. 41 tahun 2004 tentang wakaf. Ijtihad: Jurnal Wacana Hukum Islam dan Kemanusiaan, 12(2), 123. https://doi.org/10.18326/ijtihad.v12i2.123-143

22. Hoecke, V. M., \& Warrington, M. (1998). Legal Cultures, Legal Paradigms and Legal Doctrine: Towards a New Model for Comparative Law. International and Comparative Law Quarterly, 47(3), 495-536. https://doi.org/10.1017/S0020589300062163

23. Islamiyati, I., Setyowati, R., Hendrawati, D., \& rofiq, A. (2019). Legal Renewal of Cash Waqf Law Through Legal System Approach. Proceedings of the The First International Conference On Islamic Development Studies 2019, ICIDS 2019, 10 September 2019, Bandar Lampung, Indonesia. The First International Conference On Islamic Development Studies 2019, ICIDS s2019, 10 September 2019, Bandar Lampung, Indonesia, Bandar Lampung, Indonesia. https://doi.org/10.4108/eai.10-9-2019.2289333

24. Khademolhoseini, M. (n.d.). Cash-Waqf A New Financial Instrument for Financing Issues: An Analysis of Structure and Islamic Justification of Its Commercialization. Imam Shadiq University.

25. Koentjaraningrat. (1991). Metode Wawancara. In Metode Penelitian Masyarakat (II). Gramedia.

26. Mahamood, S. M., \& Ab Rahman, A. (2015). Financing universities through waqf, pious endowment: Is it possible? Humanomics, 31(4), 430-453. https://doi.org/10.1108/H-02-2015-0010

27. Masdar. (n.d.). Penerapan Hukum Wakaf Uang di Indonesia Perspektif Legal System Theory. Al-Manahij, 11(1), 2017. https://doi.org/10.24090/mnh.v11i1.1269

28. Mehmood, M. I., Chishti, S. A., \& Mughal, M. J. (2015). Islamic concept of Fatwa, Practice of Fatwa in Malaysia and Pakistan: The Relevance of Malaysian Fatwa model for legal system of Pakistan. International Research Journal of Social Sciences, 4(9), 6.

29. Mohamad, N. A. (n.d.). Waqf Lands and Challenges from the Legal Perspectives in Malaysia. 9.

30. Mohammad, M. T. S. H. (2011). Toward an Islamic Social Waqf) Bank. International Journal of Trade, Economics and Finance, 2(5), (381-386. https://doi.org/10.7763/IJTEF.2011.V2.135

31. Mohsin, M. I. A., Dafterdar, H., Cizakca, M., Alhabshi, S. O., Razak, S. H. A., Sadr, S. K., Anwar, T., \& Obaidullah, M. (2016). Financing the Development of Old Waqf Properties. Palgrave Macmillan US. https://doi.org/10.1057/978-1-137-58128-0

32. Moleong, L. J. (1989). Metode Penelitian Kualitatif. Remaja Karya.

33. Mu'allim, A. (2015). Pengaruh Pengelolaan Wakaf di Mesir terhadap Pengelolaan Harta Wakaf Pendidikan di Indonesia: Studi terhadap Ijtihad dalam Pengelolaan Wakaf Pendidikan di UII dan Pondok Modern Gontor. Akademika Jurnal Pemikiran Islam, 20(01), 20.

34. Mughnisani, F., \& Lutfi, M. (2013). Pengelolaan Wakaf uang di Yayasan Wakaf UMI. Laporan Penelitian, 18.

35. Nazir, M. (1988). Metode Penelitian. Ghalia Indonesia.

36. Norzilan, N. I. (2018). Waqf in Malaysia and Its New Waves in the Twenty-First Century. Kyoto Bulletin of Islamic Area Studies, 11, 140-157.

37. Nurrachmi, R. (2013, February 27). The Implication of Cash Waqf in the Society. MPRA Paper No. 44605.

38. Nuzul, A. (2017). The Melting Pot Of Legal Systems In Indonesia (Reading The Legal Politics Of Indonesian Islamic Law). PROCEEDINGS ICTESS UNISRI, 1(1), 11.

39. Othman, Y. H.-, Fisol, W. N. M., Saufi, M. S. A. M., \& Abdullah, M. B. (2017). Financing Kolej Universiti INSANIAH Using the Concept of Cash Waqf: The Way Forward. International Journal of Academic Research in Business and Social Sciences, 7(11). https://doi.org/10.6007/IJARBSS/v7-i11/3551

40. Qahaf, M. (2006). Al-Waqfu al-Islami: Tatawuruhu, Idaratuhu, Tanmiyatuhu. Dar al-Fikr.

41. Rosadi, A., \& Effendi, D. (2018). The Development of Waqf Management Trhought Waqf Act in Indonesia. Madania, 22(1), 18. https://doi.org/10.29300/madania.v22i1.881

42. Rusdjin. (2019, June 4). Praktif Wakaf Uang di Universitas Muslim Indonesia [Personal communication].

43. Salleh, M. binti, \& Abdul Rahman, N. S. binti. (2014, November 17). Wakaf Pendidikan di Malaysia: Satu Tinjauan. International Research Management and Innovation Conference 2014 (IRMIC2014), Kuala Lumpur.

44. Soekanto, S. (1986). Pengantar Penelitian Hukum. UI Press.

45. Suryani, \& Isra, Y. (2016). Wakaf Produktif (Cash Waqf) dalam PerspektifHukum Islam dan Maqāṣid AlSharī'Ah. Walisongo: Jurnal Penelitian Sosial Keagamaan, 24(1), 17-36. https://doi.org/10.21580/ws.24.1.680

46. Sutopo, H. (1988). Pengantar Penelitian Kualitatif. Puslit UMS.

47. Suwarsono, M. (2019, June 27). Manajemen Wakaf Uang di Universitas Islam INdonesia [Personal communication].

48. Sya'bani, A. (2016). Wakaf Uang (Cash Waqf, Waqf An-Nuqûd); Telaah Teologis Hingga Praktis. El-Hikam Journal of Education and Religious Studies, 9(1), 160-186.

49. Tim Direktorat Wakaf-Dirjen Bimas Islam Kemenag RI. (2013). Strategi Pengembangan Wakaf uang di Indonesia. Direktorat Wakaf-Dirjen Bimas Islam Kemenag RI.

50. Yaacob, H. (2013). Waqf History And Legislation In Malaysia: A Contemporary Perspective. 3(6), 17.

51. Yunus, N. R. (2015). Menciptakan Budaya Hukum Masyarakat Indonesia dalam Dimensi Hukum Progresif. 11, 20. 